\title{
Research on factors affecting bus fire based on numerical simulation
}

\author{
Min $\mathrm{Xu}^{\mathrm{a}, \mathrm{b}}$, Pengyi $\mathrm{Bu}^{\mathrm{c}}$, Lin Xin ${ }^{\mathrm{a}, \mathrm{b}^{*}}$, Chao Li ${ }^{\mathrm{a}}$, Limin $\mathrm{Han}^{\mathrm{a}}$, Mingyu $\mathrm{An}^{\mathrm{a}}$, Mingze Feng ${ }^{\mathrm{a}}$, and \\ Kaixuan $\mathrm{Li}^{\mathrm{a} *}$ \\ ${ }^{a}$ College of Safety and Environmental Engineering, Shandong University of Science and \\ Technology, Qingdao, Shandong 266590, China; \\ ${ }^{b}$ Key Laboratory of Ministry of Education for Mine Disaster Prevention and Control, \\ Shandong University of Science and Technology Shandong, Qingdao, Shandong 266590, \\ China; \\ 'Taipu Kuangye Engineering Co., Ltd., Ordos City, Inner Mongolia 017205, China
}

\begin{abstract}
With the rapid development of economy, the number of buses and bus fire increases. This paper takes bus as the research object and uses software FDS to explore the fire smoke spread under different fire power conditions. The results show that: with the increase in fire power, the smoke in the compartment rapidly accumulates, and the heating rate is also accelerated. The visibility decreases with the diffusion of smoke in the compartment. The $\mathrm{CO}$ concentration increases with time. The greater the fire power, the higher the temperature which will eventually stabilize. Only the concentration of smoke near the entrance will be slightly reduced. This is also conducive to the escape of people inside the car.
\end{abstract}

\section{Introduction}

With the rapid development of economy and the acceleration of urbanization, more and more buses have entered the city, and the number of bus fires has increased. The space of the bus is small, and a large amount of combustibles accumulate. In the event of a fire, the fire will develop rapidly, and the flue gas will fill the entire car in a short time, which will easily cause casualties and significant economic losses. In recent years, frequent bus fire accidents have seriously affected road traffic order and social harmony and stability ${ }^{[1]}$. Limited cabin space, personnel density and suburban location of the running train lead to difficulties in firefighting and evacuation ${ }^{[2]}$. The casualties caused by smoke from the fire of the cabin are mainly due to its toxicity, high temperature and shading characteristics ${ }^{[3,}$ 4].Therefore, studying the bus fire characteristics and their inherent development laws has become an important issue related to people's livelihood issues.

Many research institutes and research scholars have done a lot of experiments on bus fires. Chen and other scholars studied a fire accident occurred in the Hsuehshan southbound road tunnel. Then they used Fire dynamics simulator (FDS) software to simulate the smoke movement in the $13 \mathrm{~km}$ southbound road tunnel, employing more than 21 million computational cells ${ }^{[5]}$. Mo et al analyzed of smoke Hazard in train compartment fire

* Corresponding author: Lin Xin, xinlinsdust@sdust.edu.cn 
accidents and used CFD method based on the FDS to analyze the main features of fire smoke on the human body injury; simulate smoke flow caused by compartment fire ${ }^{[6]}$. Hu et al analyzed Hsuehshan tunnel fire in Taiwan, which occurred from a bus fire in the afternoon of May 7, 2012. They used fire dynamics simulator to investigated fire temperature, smoke layers and situation of people in the tunnel refuge area. The results show that the fire temperature reaches $800-900^{\circ} \mathrm{C}$ and HRR is about $25-30 \mathrm{MW}$, which is consistent with the accident review and experimental data ${ }^{[7]}$. Wang et al assessed the influence of fuel geometrical shape on fire dynamics simulator (FDS) predictions for a large-scale heavy goods vehicle tunnel fire experiment ${ }^{[8]}$. In 2016, Ola Willstrand et al used FDS to conduct fire detection of toilet compartments and driver's sleeper compartments of buses and buses based on full-scale test installation considerations ${ }^{[9]}$. Ali Haghighat et al studied road tunnel fire simulation tunnel with CFD data to quantify the significance dimensions, inlet velocity, heat release rate, size and fire of fluid characteristics downstream of physical fire (fire perimeter) ${ }^{[10]}$. Luo et al investigated the effect of vehicular blocking scene on the smoke spread in the longitudinal ventilated tunnel fire by using FDS as the fire dynamic simulator. The results show that the blockage area ratio has significant influence on the maximum temperature and smoke diffusion range under the tunnel roof ${ }^{[11]}$. Liang et al carried out the emergency evacuation experiment of electric buses for three different scenes and compared the experimental results with the simulation results by STEPS ${ }^{[12]}$. In 2010, Chen ${ }^{[13]}$ and $\operatorname{Sun}^{[14]}$ et al studied the car's fire location, fire cause, combustion performance, fuel tank material, oil quantity and laboratory circumference. In 2012, the Hangzhou Fire Department conducted a fire test using a long-distance bus and found that the bus was covered by fire within one minute of the fire ${ }^{[15]}$. Cheng et al studied the variation of fire temperature and heat release rate in the car over time, and obtained the best escape time ${ }^{[16]}$. In 2012, Zhu et al studied interior decoration and obtained combustion control methods for decorative materials ${ }^{[17]}$. With the rapid development of computer technology and fire science, data simulation technology is used to obtain relevant data after vehicle-oriented simulation research. The economically effective fire rescue personnel test is carried out. In 2010, Bi et al used fire simulation software to simulate the bus fire, and obtained the peak smoke density, temperature distribution, smoke component concentration, and other time-varying rules of heat release rate of bus fire ${ }^{[18]}$. In 2012 , Zhu et al constructed the whole process from the fire to the end of the combustion of the bus. The results of the software simulation showed that the toxic gas generated by the fire and the high temperature inside the car were caused by the $\operatorname{car}^{[19]}$. In 2012, Pan used software FDS to carry out the bus numerical simulation analysis, and the smoke movement of the fire in the car under different ventilation conditions. They obtained the fire heat release rate curve of the bus under different ventilation conditions ${ }^{[20]}$.

The above data simulation method is used to study the bus fires common models mainly in different ventilation conditions to get the best escape time for the people inside bus. There is no specific research and analysis on the impact of fire with different powers and locations on bus fires. This paper mainly analyzes the fire influence of different powers and different locations on the smoke spread in the bus.

This paper takes the most common bus as the simulation research object. Through on-the-spot understanding, a simple model construction of the bus is carried out. The fire simulation software $\operatorname{FDS}^{[21,22]}$ is used to simulate the temperature distribution, CO concentration and visibility of the bus in the bus fire. Then the obtained data are processed and the smoke spread rule of the bus fire is analyzed. 


\section{Experimental and numerical set up}

\subsection{Establishment of bus Model}

This paper takes ordinary single-decker buses as the reference of real buses. The exterior dimensions of buses are $11990 \mathrm{~mm}$ x $2550 \mathrm{~mm}$ x $2970 \mathrm{~mm}$. Establishment of Simple Bus Model. The basic information of the model is shown in Table 1. The simplified model of the bus is shown in the Fig.1 and Fig. 2.

Table 1. Basic information on bus models

\begin{tabular}{cc}
\hline project & data \\
\hline $\begin{array}{c}\text { Appearance } \\
\text { Dimensions of Buses }\end{array}$ & $20 \mathrm{~m} \times 3 \mathrm{~m} \times 3.5 \mathrm{~m}$ \\
\hline $\begin{array}{c}\text { Effective Height } \\
\text { of Vehicle Interior } \\
\text { Space }\end{array}$ & $3 \mathrm{~m}$ \\
\hline Temperature in Buses & $0.5 \mathrm{~m}$ \\
\hline $\begin{array}{c}\text { Thickness of } \\
\text { wagon }\end{array}$ & Except for the front door, there is a $0.5 \mathrm{~m}$ gap between the back \\
\hline $\begin{array}{l}\text { Ventilation of } \\
\text { integral buses }\end{array}$ & \\
\hline
\end{tabular}

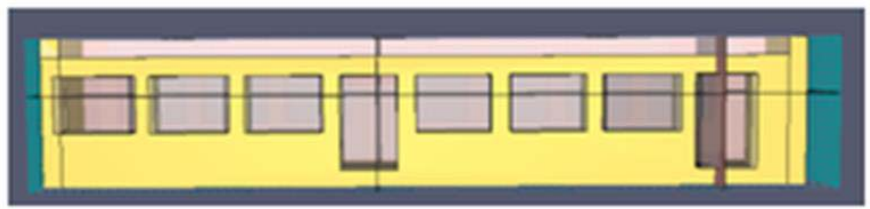

Fig. 1. Positive view of the bus

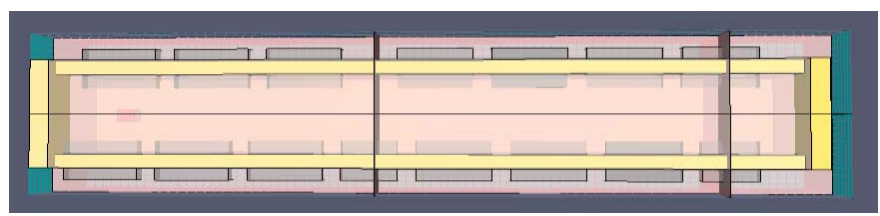

Fig. 2. Preview of the bus

\subsection{Arrangement of detection points and surfaces}

Temperature, visibility and $\mathrm{CO}$ concentration slices were set on $\mathrm{x}, \mathrm{y}$ and $\mathrm{Z}$ axes respectively in the model (Fig. 3). The detection points were set at $2.5 \mathrm{~m}, 8.5 \mathrm{~m}, 18.5 \mathrm{~m}$ from the fire source and $2.5 \mathrm{~m}$ from the door frame along the center of the channel. Detections were set at $9 \mathrm{~m}, 18 \mathrm{~m}$ and in the middle of the carriage. Detection surface is set to detect the 
temperature, visibility and $\mathrm{CO}$ concentration in the carriage with time.

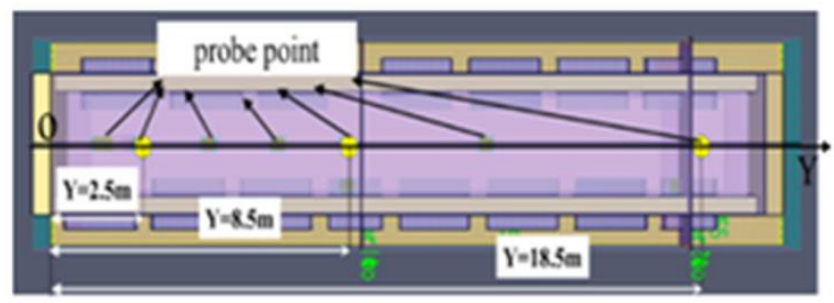

Fig. 3. Distribution of detection points in carriages

The car window inside the model is closed, the door is also closed, the pressure of the boundary is the standard atmospheric pressure, the bus is at rest, and only the connection position of the door and the car body is used for ventilation. Under the above conditions, the characteristics of the smoke in the car and the changes in the temperature, visibility and $\mathrm{CO}$ concentration in the car with time are studied.

\subsection{Setting of bus fire scene}

This article selects the steady-state fire $T^{2}$ fire. The $T^{2}$ fire represents the most serious fire scene that can occur. Researcher Klote has proposed a conclusion about the power setting: some relatively limited space for fuel, the heat release rate per unit area in space can be 225 $\mathrm{Kw} / \mathrm{m}^{2}$; however, when there are more flammable materials and combustibles in the space, the heat release rate can be $500 \mathrm{~kW} / \mathrm{m}^{2[23]}$. According to the test on fire combustion done $i^{[24]}$, it can be obtained that the heat release rate of the oil pool fire of $0.5 \mathrm{~m} \times 0.5 \mathrm{~m}$ is $151.2 \mathrm{~kW}$. Usually, the heat release rate of buses during combustion is difficult to reach 500 $\mathrm{kW} / \mathrm{m}^{2}$, but considering special circumstances such as artificial arson, combustion of flammable and explosive materials, combustion of bus fuel tank, etc. Therefore, different heat release rates are selected in this paper, which are $500 \mathrm{~kW} / \mathrm{m}^{2}, 750 \mathrm{~kW} / \mathrm{m}^{2}, 1,000$ $\mathrm{kW} / \mathrm{m}^{2}$ and $1,500 \mathrm{~kW} / \mathrm{m}^{2}$, respectively. The burning area of the fire source is set to $0.5 \mathrm{~m} \mathrm{x}$ $0.5 \mathrm{~m}$.

\section{Result and discussion}

In this paper, the software FDS 2016 version is used. The bus model built by the software runs for 600 seconds in case of fire. The changes of temperature, visibility and $\mathrm{CO}$ concentration in the carriage under different fire power and different fire location are calculated. The fire source is placed at $\mathrm{y}=1.25 \mathrm{M}$.

\subsection{Analysis of fire smoke spread in bus}

Taking $1000 \mathrm{~kW} / \mathrm{m}^{2}$ fire as the research object, the development of bus fire is analyzed. Fig. 4 shows the smoke distribution in the carriage at different time after the fire occurs. 


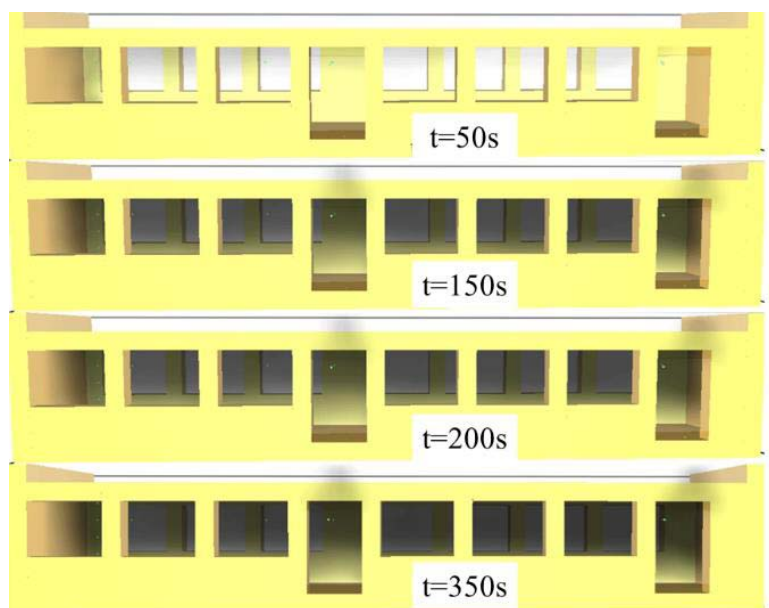

Fig. 4. Distribution of flue gas in bus carriages over time

As can be seen from Fig. 4, when the fire occurs for $50 \mathrm{~s}$, the smoke flow gradually rises. After touching the roof, it diffuses around. With the time increase, the flue gas gradually accumulates and begins to press down after accumulating to a certain concentration. Because of the space limitation, the flue gas has been spreading downward. With the time passage, the smoke in the carriage is getting stronger and stronger.

\subsection{Bus fire analysis under different fire power}

The data of four positions were analyzed by $y=2.5 \mathrm{~m}, \mathrm{y}=8.5 \mathrm{~m}, \mathrm{z}=18.5 \mathrm{~m}$ and back door respectively.

\subsubsection{Temperature Change}
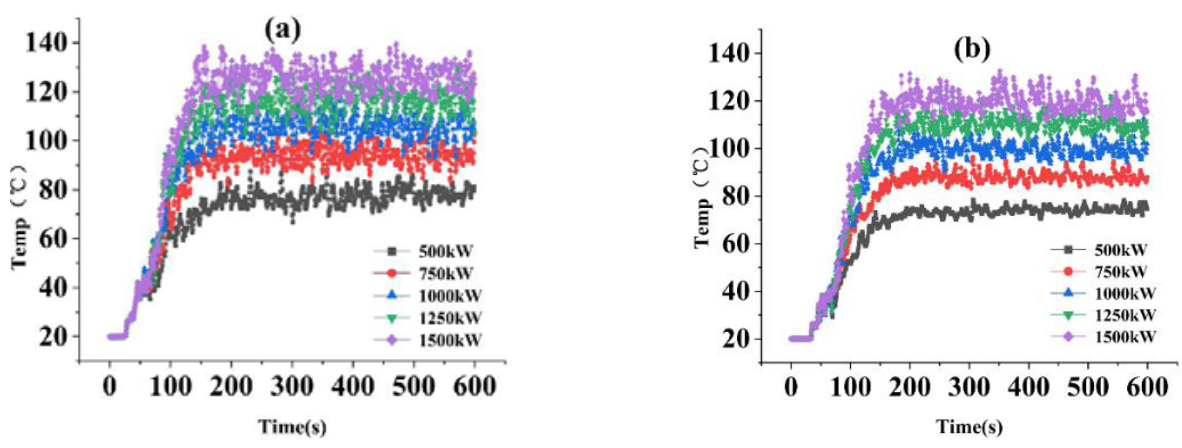

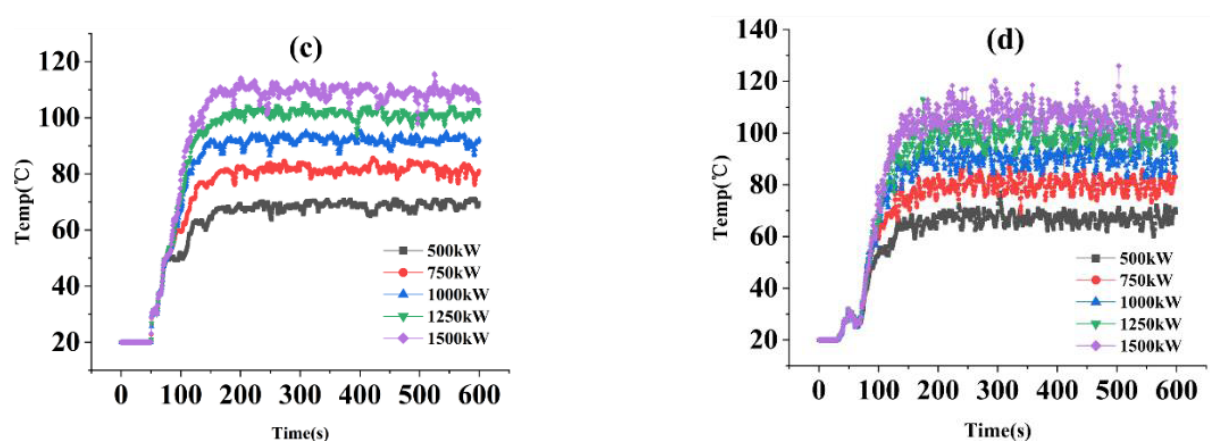

Fig. 5. Temperature variation within the drop of different power at the same location

(a) $2.5 \mathrm{~m}$ from the fire ; (b) $8.5 \mathrm{~m}$ from the fire; (c) $18.5 \mathrm{~m}$ from the fire; (d)Rear door

From Fig. 5, it can be seen that the temperature in the carriage has nothing to do with the fire power within $45 \mathrm{~s}$. It has always been maintained at $20^{\circ} \mathrm{C}$. Within $50 \mathrm{~s}$ to $100 \mathrm{~s}$, the temperature in the carriage rises rapidly at different power levels. After burning for a period of time, the temperature in the carriage tends to be stable at about $150 \mathrm{~s}$. And the higher the fire power, the higher the final temperature it reaches. When the detector's temperature is $500 \mathrm{~kW}$, the change rate of temperature with time is the slowest, and with the fire power increase, the change rate also increases. At the distance of $2.5 \mathrm{~m}$ from the fire of $500 \mathrm{~kW}$, the maximum endurance temperature of the human body reaches $60{ }^{\circ} \mathrm{C}$. Because of its rapid combustion and vigorous fire, the $1500 \mathrm{~kW}$ power detector reaches $60{ }^{\circ} \mathrm{C}$. It burns rapidly in $45 \mathrm{~s}$ until a stable high temperature of $130{ }^{\circ} \mathrm{C}$. The temperature of the detection point at $18.5 \mathrm{~m}$ away from the $500 \mathrm{~W}$ fire reached $60{ }^{\circ} \mathrm{C}$ when the fire burned to $140 \mathrm{~s}$. It reached $70{ }^{\circ} \mathrm{C}$ when the fire burned to about $175 \mathrm{~s}$. The detection temperature at $18.5 \mathrm{~m}$ reached $60{ }^{\circ} \mathrm{C}$ at $90 \mathrm{~s}$, and then burned rapidly to the maximum $110^{\circ} \mathrm{C}$ within $50 \mathrm{~s}$. It tended to be stable in the following time. In the rear door, the $500 \mathrm{~kW}$ fire burns for $125 \mathrm{~s}$. The temperature reaches $60{ }^{\circ} \mathrm{C}$, and then reaches $65{ }^{\circ} \mathrm{C}$ in the next $20 \mathrm{~s}$. When the 1,500 $\mathrm{kW}$ fire burns for $95 \mathrm{~s}$, it reaches $60{ }^{\circ} \mathrm{C}$, then burns rapidly. It reaches the maximum temperature at $150 \mathrm{~s}$.

\subsubsection{Changes in visibility}
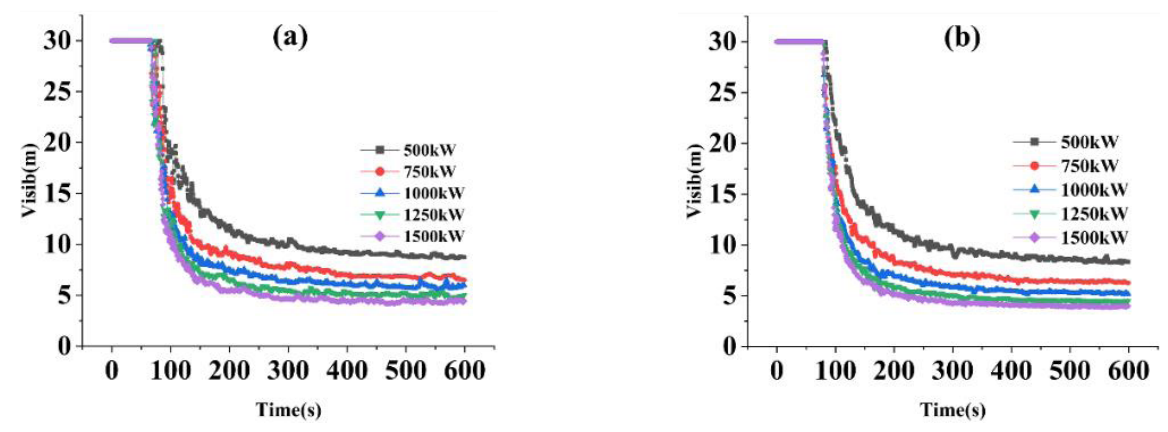

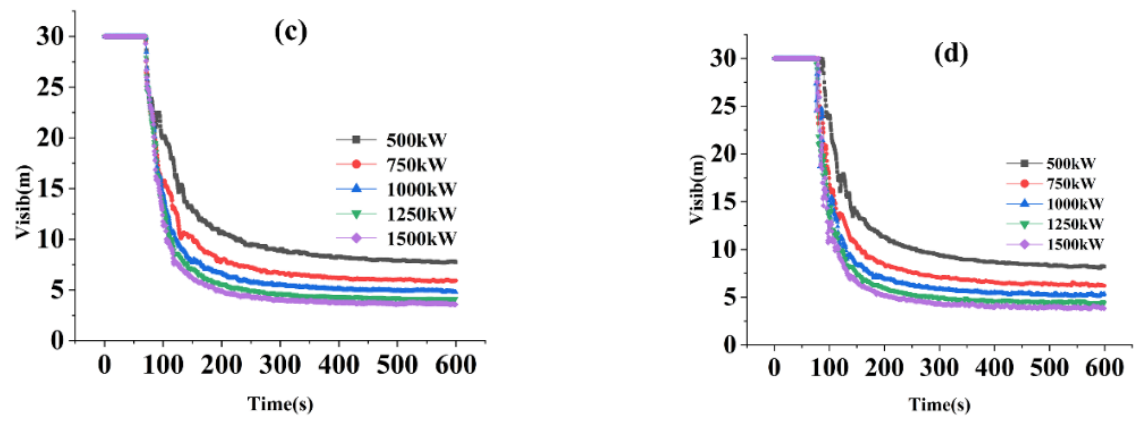

Fig. 6. Variation in visibility of different sources of fire power at the same location

(a) $2.5 \mathrm{~m}$ from the fire source; (b) $8.5 \mathrm{~m}$ from the fire source; (c) $18.5 \mathrm{~m}$ from the fire source ; (d)Rear door

As can be seen from Fig. 6, with the increase of the fire power, the bus fire is increasing, the smoke is also generating and accumulating, and the movement of the smoke is accelerating. Under $500 \mathrm{~kW}$ fire, the visibility of detector at $2.5 \mathrm{~m}$ distance reaches $10 \mathrm{~m}$ of normal human visibility in about $250 \mathrm{~s}$. In $50 \mathrm{~s}$, it decreases to $8 \mathrm{~m}$ and tends to be stable. The visibility of the detector at a distance of $18.5 \mathrm{~m}$ decreases to $10 \mathrm{~m}$ at $175 \mathrm{~s}$ and to $7.5 \mathrm{~m}$ at $350 \mathrm{~s}$. At the rear door position, the visibility decreases to $10 \mathrm{~m}$ at $225 \mathrm{~s}$ and to $9 \mathrm{~m}$ at $300 \mathrm{~s}$. The visibility at a distance of $2.5 \mathrm{~m}$ has been reduced to $10 \mathrm{~m}$ at $100 \mathrm{~s}$ and to $5 \mathrm{~m}$ at $250 \mathrm{~s}$, and it has remained stable all the time. The visibility at a distance of $18.5 \mathrm{~m}$ is $10 \mathrm{~m}$ at $125 \mathrm{~s}$ and the lowest is $3 \mathrm{~m}$ at $300 \mathrm{~s}$. The visibility at the rear door decreases to $10 \mathrm{~m}$ at $110 \mathrm{~s}$ and to the lowest $4 \mathrm{~m}$ at $280 \mathrm{~s}$, and remains stable.

\subsubsection{Changes in CO Concentration}
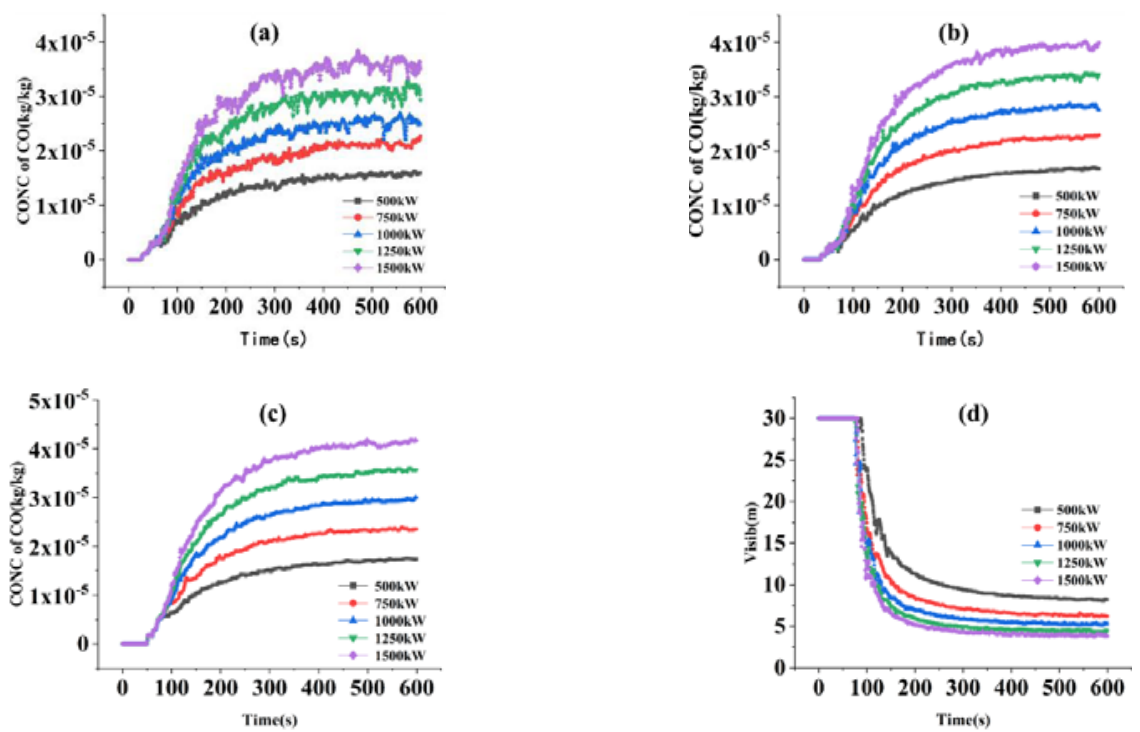

Fig. 7. Changes in $\mathrm{CO}$ concentration in different source power vehicles at the same location (a) $2.5 \mathrm{~m}$ from the fire source; (b) $8.5 \mathrm{~m}$ from the fire source; (c) $18.5 \mathrm{~m}$ from the fire source; 


\section{(d)Rear door}

As can be seen from Fig. 7, with the increase of power, the burning rate of the fire in the car is also increasing, the smoke is also constantly generating accumulation and diffusion, and the poisonous gas is also increasing. When the fire power is $500 \mathrm{~kW}$, the $\mathrm{CO}$ concentration reaches $0.001 \%$ at $200 \mathrm{~s}$ at $2.5 \mathrm{~m}$ away from the fire, $0.0015 \%$ at about $250 \mathrm{~s}$ at $18.5 \mathrm{~m}$ away from the fire, and $0.00125 \%$ at $250 \mathrm{~s}$ at the bus rear door. When the fire power is $1,500 \mathrm{~kW}$, the CO concentration reaches $0.0035 \%$ at $2.5 \mathrm{~m}$ from the fire position, and the concentration fluctuates around $0.0035 \%$ in the next time; $18.5 \mathrm{~m}$ from the fire position. The CO concentration reached $0.004 \%$ at $300 \mathrm{~s}$ and remained stable; the CO concentration at the back door of the car reached $0.0035 \%$ at $300 \mathrm{~s}$ and remained relatively stable for the next period of time.

\section{Conclusions}

1.Through simulation analysis, it is found that the fire spread and the smoke diffusion are accelerated. The influence on the concentration of smoke is small, and only the concentration of smoke near the door is concentrated.

2.With the increase of fire power, the rate of temperature rises and the final stable temperature in the carriage increases.

3.Visibility in carriages with different fire power decreases rapidly in $90 \mathrm{~s}-100 \mathrm{~s}$, and reaches stability in about $110 \mathrm{~s}$.

4.After $90 \mathrm{~s}$ of combustion, the higher the power, the more flue gas produced and the faster the diffusion rate, so the concentration of $\mathrm{CO}$ increases with the increase of flue gas.

\section{Acknowledgements}

This study was financially supported by the National Natural Science Foundation of China (No. 51504142, No. 51674157), the Scientific Research Foundation of Shandong University of Science and Technology for Recruited Talents (No. 2017RCJJ013), the First-class Discipline Construction Special Fund Project of College of Mining and Safety Engineering, Shandong University of Science and Technology (No. 01AQ02105), the SDUST Research Fund (No. 2018TDJH102).

\section{References}

1. Y. Xia, Analysis on the city bus fire accident prevention measures (2010)

2. H.B. Du, X.Y. Qi, Journal of Thermal Science and Technology, 31 (1999)

3. C.F. Liu, N. Pen, Journal of Thermal Science and Technology, 352 (2003)

4. Y. Tang, Q. Geng, Applied Energy Technology, 28 (2007)

5. Y. Chen, C. Shu, S. Ho, H. Kung, S. Chien, H. Ho, W. Hsu, Tunnelling and Underground Space Technology, 84, 142 (2019)

6. S. Mo, Z. Li, D. Liang, J. Li, N. Zhou, Procedia Engineering, 52, 284 (2013)

7. W. Hsu, Y. Huang, T. Shen, C. Cheng, T. Chen, Tunnelling and Underground Space Technology incorporating Trenchless Technology Research, 69, 108 (2017)

8. X. Wang, C. Fleischmann, M. Spearpoint, Case Studies in Fire Safety, 5, 34 (2016)

9. O. Willstrand, J. Brandt, R. Svensson, Case Studies in Fire Safety, 5 (2016) 
10. A. Haghighat, K. Luxbacher, International Journal of Mining Science and Technology, 29, 185 (2019)

11. J. Luo, Z. Xu, F. Li, J. Zhao, Case Studies in Thermal Engineering, 14 (2019)

12. J. Liang, Y. Zhang, H. Huang, Procedia Engineering, 211, 427 (2018)

13. W. Chen, Fire Science and Technology, 75, 379 (2010)

14. X. Sun, Y. Li, K. Zhao, Fire Science and Technology, 8, 37 (2015)

15. Y. Gao, Anhui University of Science and Technology (2015)

16. Y. Cheng, R. John, Journal of China University of Mining and Technology, 31, 557 (2002)

17. L. Zhu, Z. Han, Y. Yao, Fire Science and Technology, 11, 1210 (2012)

18. K. Bi, Data simulation study of bus fire characteristics University of Science and Technology of China (2010)

19. F. Zhu, K. Bi, Journal of the Chinese People's Armed Police Force, 2, 90 (2012)

20. Y. Pan, Science and Technology Innovation Review, 9, 10 (2012)

21. K. McGrattan, R. McDermott, S. Hostikka, J. Floyd, NIST Special Publication, National Institute of Standards and Technology, 19 (2015)

22. H. A, Tunneling and Underground Space Technology, 13, 377 (1998)

23. R. Huo, H. Yuan, Performance analysis and design of building fire Anhui Science and Technology Press (2002)

24. W. Zhong, R. Huo, C. Shim, Journal of Natural Disasters, 13, 61 (2004) 